\title{
Isolation and genotyping of Clostridium perfringens from goats in Minas Gerais, Brazil
}

\author{
Jordana Almeida Santana ${ }^{1}$ Ana Carolina de Andrade Ferreira ${ }^{1}$ Marina de Castro Campos de Souza ${ }^{2}$ \\ Maria Aparecida Scatamburlo Moreira $^{2}$ Magna Coroa Lima ${ }^{2}$ Diogo Soares Gonçalves Cruz ${ }^{1}$ \\ Francisco Carlos Faria Lobato ${ }^{1}$ Rodrigo Otávio Silveira Silva ${ }^{1^{*}}$
}

${ }^{1}$ Escola de Veterinária, Universidade Federal de Minas Gerais (UFMG), Antônio Carlos Avenue, 6627, 31270-901, Belo Horizonte, MG, Brasil. E-mail: rodrigo.otaviosilva@gmail.com. "Corresponding author.

${ }^{2}$ Departamento de Medicina Veterinária, Universidade Federal de Viçosa (UFV), Viçosa, MG, Brasil.

ABSTRACT: Despite the known importance of Clostridium perfringens as an enteropathogen in small ruminants, little is known about the role of its additional virulence factors or the frequency of the various $C$. perfringens genotypes in healthy goats; this complicates the laboratory diagnosis of the infections caused by this microorganism. In light of this, the aim of the present study was to isolate and genotype C. perfringens from stool samples from healthy goats in Brazil. Stool samples from 250 apparently healthy adult goats from 17 different herds in Minas Gerais, Brazil were collected, and isolation and genotyping of C. perfringens was performed. C. perfringens type A was isolated from 189 (75.6\%) goats, whereas $C$. perfringens types $C$ and $D$ were each detected in one goat $(0.4 \%)$. All isolates were negative for enterotoxin-, NetB-, NetE-, and NetF-encoding genes. These results confirmed $C$. perfringens type $A$ as part of the microbiota in these animals, and they suggested that $C$. perfringens type $C$ and $D$ are rarely isolated from healthy goats.

Key words: Clostridium perfringens type D, microbiota, epsilon, beta.

Isolamento e genotipagem de Clostridium perfringens isolados de cabras em Minas Gerais, Brasil

RESUMO: Apesar da reconhecida importância de Clostridium perfringens como enteropatógeno de pequenos ruminantes, pouco se sabe sobre a frequência dos genótipos ou do papel de fatores de virulência adicionais de C. perfringens em cabras saudáveis, dificultando o diagnóstico laboratorial da infecção causada por esse micro-organismo. Dessa forma, o presente estudo teve como objetivo caracterizar C. perfringens de amostras de fezes de cabras adultas saudáveis. Amostras de fezes de 250 cabras saudáveis de 17 rebanhos diferentes em Minas Gerais, Brasil, foram submetidas ao isolamento e genotipagem de C. perfringens. C. perfringens tipo A foi isolado de 189 (75,6\%) cabras, enquanto $C$. perfringens tipos $C$ e D foram detectados em um animal (0.4\%) cada. Todos os isolados foram negativos para os genes codificadores das toxinas NetB, NetE, NetF e enterotoxina. Os resultados apresentados confirmam C. perfringens tipo A como parte da microbiota de cabras saudáveis e sugere que C. perfringens tipos C e D são raramente encontrados em caprinos saudáveis.

Palavras-chave: Clostridium perfringens tipo D, microbiota, épsilon, beta.

Clostridium perfringens is classified into five types (A-E) based on the capacity to produce one or more of the four major toxins (alpha, beta, epsilon, and iota). C. perfringens type $\mathrm{A}$ is commonly isolated as part of the microbiota in animals and humans, whereas the other types are rarely isolated from healthy individuals (UZAL et al., 2014). In addition to the four major toxins, $C$. perfringens can produce several additional virulence factors that are associated with disease in humans and some domestic animals (LINDSTRÖM et al., 2011; SILVA \& LOBATO, 2015). In the last few years, three pore-forming toxins (NetB, NetE, and NetF) have been described in $C$. perfringens strains from broiler chicken, horses, and dogs with enteritis (KEYBURN et al., 2008;
GOHARI et al., 2015). However, there is no study evaluating the presence of the genes for these toxins in C. perfringens isolates from goats.

Enterotoxaemia caused by $C$. perfringens type D is a disease of great economic and sanitary importance for ruminants farming worldwide, including in Brazil (BALDASSI et al., 1995; COLODEL et al., 2003; OLIVEIRA et al., 2010; SUMITHRA et al., 2013). The detection of the epsilon toxin in intestinal contents or stool samples using the serum neutralization test in mice or enzyme-linked immunosorbent assay (ELISA) is considered the "gold standard" method to diagnose enterotoxaemia; however, these techniques are available in very few laboratories. In addition, the epsilon toxin is 
extremely unstable, which commonly leads to falsenegative results (SUMITHRA et al., 2013). Therefore, a diagnosis of enterotoxaemia is commonly based on the combination of history, clinical signs, and isolation of $C$. perfringens type D in the intestinal contents of the affected animals (SUMITHRA et al., 2013; UZAL et al., 2014). Despite the importance of $C$. perfringens type $\mathrm{D}$ as an enteropathogen in goats, there have been few studies on $C$. perfringens in healthy individuals, and none has been conducted in Brazil. The majority of studies included only samples from diseased animals (UZAL et al., 1996; MISEREZ et al., 1998; UZAL et al., 2008). Thus, the frequency of $C$. perfringens type D in healthy animals, which can influence the laboratory diagnosis of enterotoxaemia in these animals, is still not known.

$C$. perfringens type $\mathrm{A}$ has also been described as a cause of enteric disease in goats (DRAY, 2004; MIYAKAWA et al., 2007). Once it was commonly recovered from healthy animals; several studies have been conducted to detect the additional virulence factors that could be used as markers in the diagnosis of $C$. perfringens-associated disease in domestic animals (KEYBURN et al., 2008; GOHARI et al., 2015). However, no study has evaluated the frequency of these recent described virulence factors in healthy goats.

Thus, the absence of information regarding the types of $C$. perfringens in healthy goats and the absence of studies on the role of additional virulence factors complicate the laboratory diagnosis of the infections caused by this microorganism. In light of this, the aim of the present study was to isolate and genotype $C$. perfringens from stool samples from healthy goats in Brazil.

Stool samples from 250 apparently healthy adult goats from 17 different herds in Minas Gerais, Brazil, were collected. To perform the isolation of C. perfringens, $0.08-0.12 \mathrm{~g}$ of feces were serially diluted by factors of 10 , ranging from $10^{-1}$ to $10^{-3}$. Aliquots of $10 \mu \mathrm{l}$ of each dilution were plated on sulfite-polymyxin-sulfadiazine agar (SPS, Difco Laboratories, USA) and anaerobically incubated at $37^{\circ} \mathrm{C}$ for 24 hours (SILVA et al., 2013). After the incubation, at least three sulfite-reducing colonies from each dilution were tested using a previously described PCR protocol (VIEIRA et al., 2008) for the detection of genes encoding the major $C$. perfringens toxins (alpha, beta, epsilon, and iota), beta-2 toxin (cpb2), and enterotoxin (cpe). For the detection of the NetB-, NetE-, NetF-, and NetG-encoding genes (net $B$, net $E$, netF, and net $G$, respectively), the PCR protocols described by KEYBURN et al. (2008) and GOHARI et al. (2015) were applied. The following strains were used as positive controls: $C$. perfringens ATCC 3629, C. perfringens ATCC 3626, C. perfringens D7 (net $E^{+}$, net $F^{+}$, net $G^{+}$, cpe $^{+}$), and $C$. perfringens $\mathrm{CP} 149$ (tpe $L^{+}$, net $B^{+}$).

$C$. perfringens was isolated from 191 $(76.4 \%)$ of the goats sampled (Table 1). In the present study, even though three colonies were tested per animal, none of the goats had more than one genotype. Thus, only one isolate per goat was further analyzed. $C$. perfringens type A (positive only for alpha-toxinencoding gene) was the most common genotype, corresponding to $98.9 \%(189 / 191)$ of isolates. This isolation rate is similar to the ones previously described in other ruminant and non-ruminant domestic animals (SIPOS et al., 2003; FARZAN et al., 2013; SILVA et al., 2013; SILVA \& LOBATO, 2015; SILVA et al., 2015; DINIZ et al., 2017), and it confirmed that $C$. perfringens type $\mathrm{A}$ is common as part of the microbiota in goats.

C. perfringens type E, previously reported as a possible enteropathogen in goats and calves (SONGER \& MISKIMMINS, 2004; KIM et al., 2013), was also not detected in the present study. $C$. perfringens type $\mathrm{C}$ (strains positive for alpha- and beta-encoding genes) and D (strains positive for alpha- and epsilon-encoding genes) were each isolated from one goat $(0.4 \%)$. Previous studies in small ruminants with clinical sings of enterotoxaemia have reported a high isolation rate of this microorganism (MISEREZ et al., 1998; UZAL et al., 2008). Together these previous reports and the present research suggested that, in absence of techniques to detect the epsilon toxin, the isolation of $C$. perfringens followed by the detection of the epsilon-encoding gene (etx) by PCR is useful in the presumptive diagnosis of enterotoxaemia in goats.

Table 1 - Isolation and genotyping of Clostridium perfringens strains from apparently health goats $(n=250)$ in Minas Gerais, Brazil.

\begin{tabular}{lc}
\hline & $\begin{array}{c}\text { Stool samples from apparently } \\
\text { health goats }(\%)\end{array}$ \\
\hline Clostridium perfringens $^{1}$ & $191 / 250(76.4)$ \\
Type A & $189 / 250(75.6)$ \\
Type C & $1 / 250(0.4)$ \\
Type D & $1 / 250(0.4)$ \\
Negative & $59 / 250(23.6)$ \\
\hline
\end{tabular}

${ }^{1}$ All isolates were negative for net $B$, net $E$, net $F$, net $G$ and cpe genes. 
Although, some reports suggested that C. perfringens type A is cause of diarrhea in small ruminants (DRAY et al., 2004; MIYAKAWA et al., 2007), this hypothesis cannot be confirmed because there are no additional virulence factors that can be used as markers in the diagnosis of $C$. perfringens type A-associated disease in goats and sheep. In contrast, three pore-forming toxins (NetB, NetE, and $\mathrm{NetF}$ ) have been recently described to have a strong association with the enteritis caused by $C$. perfringens type A in dogs, foals, and broiler chickens (GOHARI et al., 2015). In the present work, all isolates were negative for NetB-, NetE-, and NetF-encoding genes. In addition, enterotoxin-encoding-gene (cpe), which is responsible for diarrhea in humans (LINDSTRÖM et al., 2011) and has previously been detected in a goat with necrotizing enterocolitis (MIYAKAWA et al., 2007), was also not detected. These results suggested that these additional virulence factors are not frequent in healthy goats. Further studies in goats with intestinal disorders can clarify if these recently described toxins play a key role in the intestinal disorders due to $C$. perfringens type A.

This is the first study on the genotypes of C. perfringens in goats in Brazil, and it had the highest number of samples compared to all other studies in the literature. The results of the present study have confirmed that $C$. perfringens type A is part of the microbiota in these animals, and they suggest that $C$. perfringens types $\mathrm{C}$ and $\mathrm{D}$ are rarely isolated from healthy goats.

\section{ACKNOWLEDGMENTS}

This research was supported by funds from: Fundação de Amparo à Pesquisa do Estado de Minas Gerais (FAPEMIG), Coordenação de Aperfeiçoamento de Pessoal de Nível Superior (CAPES), Conselho Nacional de Desenvolvimento Científico e Tecnológico $(\mathrm{CNPq})$ and Pró-Reitoria de Pesquisa da Universidade Federal de Minas Gerais. (PRPq-UFMG).

\section{BIOETHICS AND BIOSSECURITY COMMITTEE APPROVAL}

All animal procedures were approved by the Comitê de Ética em Experimentação Animal (Ethical Committee for the Use of Experimental Animals) (CEUA/ UFV), protocol 012/2013.

\section{DECLARATION OF CONFLICTING OF INTERESTS}

The authors declare no conflict of interest. The founding sponsors had no role in the design of the study; in the collection, analyses, or interpretation of data; in the writing of the manuscript, and in the decision to publish the results.

\section{REFERENCES}

BALDASSI, L. et al. Morte súbita de caprinos por enterotoxemia. Brazilian Journal of Veterinary Research and Animal Science, v. 32, n. 2, p. 109-113, 1995. Available from: <http://www.revistas.usp. br/bjvras/article/view/52097/56147>. Accessed: Feb. 03, 2018. doi: 10.11606/issn.1678-4456.bjvras.1994.52097.

COLODEL, E. M. et al. Enterotoxemia em caprinos no Rio Grande do Sul. Pesquisa Veterinária Brasileira, v. 23, n. 4, p. 173-178, 2003. Available from: <http://www.scielo.br/pdf/pvb/v23n4/18733.pdf $>$. Accessed: Feb. 03, 2018. doi: 10.1590/S0100-736X2003000400006.

DINIZ, A. N. et al. The incidence of Clostridioides difficile and Clostridium perfringens net $F$-positive strains in diarrheic dogs. Anaerobe, v. 49, n. 20, p. 58-62, 2017. Available from: <https://doi. org/10.1016/j.anaerobe.2017.12.003>. Accessed: Feb. 03, 2018. doi: 10.1016/j.anaerobe.2017.12.003.

DRAY, T. Clostridium perfringens type A and type A and $\beta 2$ toxin associated with enterotoxemia in a 5-week-old goat. The Canadian Veterinary Journal, v. 45, n. 3, p. 251-253, 2004. Available from: $<$ https://www.ncbi.nlm.nih.gov/pmc/articles/PMC548614/pdf/ cvj45pg251.pdf $>$. Accessed: Feb. 03, 2018.

FARZAN, A. et al. An investigation into the association between cpb2encoding Clostridium perfringens type A and diarrhea in neonatal piglets. Canadian Journal of Veterinary Research, v. 77, n. 1, p. 45-53, 2013. Available from: <https://www.ncbi.nlm.nih.gov/pmc/ articles/PMC3525171/pdf/cjvr_01_45.pdf $>$. Accessed: Feb. 03, 2018.

GOHARI, I. M. et al. A Novel Pore-Forming Toxin in Type A Clostridium perfringens is Associated with Both Fatal Canine Hemorrhagic Gastroenteritis and Fatal Foal Necrotizing Enterocolitis. PLoS One, v. 10, n. 4, e0122684, 2015. Available from: <https://doi. org/10.1371/journal.pone.0122684>. Accessed: Feb. 03, 2018. doi: 10.1371/journal.pone.0122684.

KEYBURN, A. L. et al. NetB, a new toxin that is associated with avian necrotic enteritis caused by Clostridium perfringens. PLoS Pathogens, v. 4, n. 2, e26, 2008. Available from: <https://www.ncbi. nlm.nih.gov/pmc/articles/PMC2233674/>. Accessed: Feb. 03, 2018. doi: 10.1371/journal.ppat.0040026.

$\mathrm{KIM}, \mathrm{H}$. Y. et al. First isolation of Clostridium perfringens type $\mathrm{E}$ from a goat with diarrhea. Anaerobe, v. 22, p. 141-143, 2013. Available from: $<$ https://www.ncbi.nlm.nih.gov/pubmed/23810805>. Accessed: Feb. 03, 2018. doi: 10.1016/j.anaerobe.2013.06.009.

LINDSTRÖM, M. et al. Novel insights into the epidemiology of Clostridium perfringens type A food poisoning. Food Microbiology, v. 28 , n. 2, p. 192-198, 2011. Available from: <https://www.ncbi. nlm.nih.gov/pubmed/21315973>. Accessed: Feb. 03, 2018. doi: 10.1016/j.fm.2010.03.020.

MISEREZ, R.; FREY, J.; BUOGO, C.; et al. Detection of $\alpha$ - and $\varepsilon-$ toxigenic Clostridium perfringens Type D in sheep and goats using a DNA amplification technique (PCR). Letters in Applied Microbiology, v. 26, p. 382-386, 1998. Available from: <http://onlinelibrary.wiley. com/doi/10.1046/j.1472-765X.1998.00356.x/pdf>. Accessed: Feb. 03, 2018. doi: 10.1046/j.1472-765X.1998.00356.x.

MIYAKAWA, M. E. et al. Necrotizing enterocolitis and death in a goat kid associated with enterotoxin (CPE)-producing Clostridium perfringens type A. The Canadian Veterinary Journal, v. 48, n. 
12, p. 1266-1269, 2007. Available from: <https://www.ncbi.nlm.nih. gov/pmc/articles/PMC2081994/pdf/cvj48pg1266.pdf>. Accessed: Feb. 03, 2018.

OLIVEIRA, D. M. et al. Focal symmetrical encephalomalacia in a goat. Journal of Veterinary Diagnostic Investigation, v. 22, n. 5, p. 793-796, 2010. Available from: <http://journals.sagepub.com/doi/ pdf/10.1177/104063871002200527>. Accessed: Feb. 03, 2018. doi: $10.1177 / 104063871002200527$.

SILVA, R. O. S.; LOBATO, F. C. F. Clostridium perfringens: A review of enteric diseases in dogs, cats and wild animals. Anaerobe, n. 33 , p. $14-17,2015$. Available from: $<$ https://www.ncbi.nlm.nih gov/pubmed/25644183>. Accessed: Feb. 03, 2018. doi: 10.1016/j. anaerobe.2015.01.006.

SILVA, R. O. S, et al. Detection of $\mathrm{A} / \mathrm{B}$ toxin and isolation of Clostridium difficile and $C$. perfringens from foals. Equine Veterinary Journal, v.45, n. 6, p. 671-675, 2013. Available from: $<$ http://www.ncbi.nlm.nih.gov/pubmed/23452044>. Accessed: Feb. 03, 2018. doi: 10.1111/evj.12046.

SILVA, R. O. S. et al. Clostridium perfringens: a review of the disease in pigs, horses and broiler chickens. Ciência Rural, v. 45, n. 6, p. 1027-1034, 2015. Available from: <http://dx.doi.org/10.1590/01038478cr20140927>. Accessed: Feb. 03, 2018. doi: 10.1590/0103$8478 \mathrm{cr} 20140927$

SIPOS, W. et al. Genotyping of Clostridium perfringens Isolated from Domestic and Exotic Ruminants and Swine. Journal of Veterinary Medicine, v. 50, p.360-362, 2003. Available from: $\quad<$ http://onlinelibrary.wiley.com/woll/doi/10.1046/j.14390450.2003.00690.x/full>. Accessed: Feb. 03, 2018. doi: 10.1046/j.1439-0450.2003.00690.x
SONGER, J. G.; MISKIMMINS, D. W. Clostridium perfringens type E enteritis in calves: two cases and a brief review of the literature. Anaerobe, v. 10, n. 4, p. 239-242, 2004. Available from: $<$ https://www. ncbi.nlm.nih.gov/pubmed/16701523>. Accessed: Feb. 03, 2018. doi: 10.1016/j.anaerobe.2004.05.001.

SUMITHRA, T. G. et al. Enterotoxaemia in goats - A review of current knowledge, Small Ruminant Research, v. 114, p. 1-9, 2013. Available from: $<$ https://doi.org/10.1016/j.smallrumres.2013.05.013>. Accessed: Feb. 03, 2018. doi: 10.1016/j.smallrumres.2013.05.013.

UZAL, F. A. et al. Ulcerative enterocolitis in two goats associated with enterotoxin- and beta2 toxin-positive Clostridium perfringens type D. Journal of Veterinary Diagnostic Investigation, v. 20, n. 5, p. 668-672, 2008.Available from: $<$ https://www.ncbi.nlm.nih.gov/pubmed/18776108>. Accessed: Feb. 03, 2018. doi: 10.1177/104063870802000526.

UZAL, F. A. et al. Detection by polymerase chain reaction of Clostridium perfringens producing epsilon toxin in faeces and in gastrointestinal contents of goats. Letters in Applied Microbiology, v. 23, n. 1, p. 13-7, 1996. Available from: <https:// www.ncbi.nlm.nih.gov/pubmed/8679138>. Accessed: Feb. 03, 2018. doi: 10.1111/j.1472-765X.1996.tb00019.x.

UZAL, F. A. et al. Towards an understanding of the role of Clostridium perfringens toxins in human and animal disease. Future Microbiology, v. 9, n. 3, p. 361-377, 2014. Available from: <https:/www.ncbi.nlm.nih.gov/ pubmed/24762309>. Accessed: Feb. 03, 2018. doi: 10.2217/fmb.13.168.

VIEIRA, A. A. S. et al. Genotipagem de Clostridium perfringens isolados de leitões diarréicos. Arquivos do Instituto Biológico, v. 75, n. 4, p. 513-516, 2008. Available from: <https://www.researchgate.net/ publication/258021724_Genotipagem_de_Clostridium_perfringens_ isolados_de_leitoes_diarreicos $>$.Accessed: Feb. 03, 2018. 